\title{
PERBANDINGAN UJI KUAT TEKAN BETON ANTAR BETON K.250 NORMAL DENGAN BETON CAMPURAN NATRIUM CLORIDA (NaCl)
}

\author{
WARNODIN ${ }^{1)}$, LEO LAPAISA ${ }^{2)}$ \\ Program Studi Teknik Sipil Fakultas Teknik \\ Universitas Palembang \\ e-mail : WarnoDin@ymail.com
}

\begin{abstract}
ABSTRAK
Beton mempunyai kuat tekan yang sangat tinggi sedang gaya tariknya rendah, dapat dibentuk sesuai keinginan, dan dapat digunakan untuk konstruksi ringan maupun berat. Kekuatan suatu bangunan dipengaruhi oleh kualitas maupun mutu beton, bahan - bahan yang dipakai dalam pembentukan beton itu sendiri salah satunya yaitu semen. Penambahan kadar semen sebesar 3\%, $6 \%$, 9\% dan $11 \%$ terhadap mutu beton K.250 diuji pada umur 7, 14 , dan 28 hari, benda uji berbentuk kubus dengan ukuran $15 \mathrm{~cm}$ x $15 \mathrm{~cm}$ x $15 \mathrm{~cm}$. Dari pengujian kubus, hasil Kuat tekan beton normal pada umur 28 hari yaitu sebesar $297,47 \mathrm{~kg} / \mathrm{cm}^{2}$, sedangkan dari hasil penambahan semen $3 \%$ pada umur 28 hari kuat tekan yang dihasilkan sebesar $309,98 \mathrm{~kg} / \mathrm{cm}^{2}$ mengalami peningkatan $4,21 \%$, penambahan semen $6 \%$ pada umur 28 hari kuattekan yang dihasilkan sebesar $316,95 \mathrm{~kg} / \mathrm{cm}^{2}$ mengalami peningkatan $6,55 \%$, penambahan semen $9 \%$ pada umur 28 hari kuat tekan yang dihasilkan sebesar $335,82 \mathrm{~kg} / \mathrm{cm}^{2}$ mengalami peningkatan $12,89 \%$ dan penambahan semen $11 \%$ pada umur 28 hari kuat tekan yang dihasilkan sebesar $340,11 \mathrm{~kg} / \mathrm{cm}^{2}$ mengalami peningkatan $14,33 \%$ dari kuat tekan beton normal. Hasil kuat tekan tertinggi didapat pada penambahan kadar semen sebesar 11\% dengan persentase kenaikan sebesar 14,33\%.
\end{abstract}

Kata Kunci : Kadar Semen, Kuat Tekan, Beton K.250

\section{PENDAHULUAN}

\subsection{Latar Belakang}

Pemakaian beton sebagai bahan konstruksi telah lama dikenal di Indonesia.Salah satu bahan utama yang sering digunakan pada konstruksi bangunan. Beton merupakan suatu material hasil dari campuran semen, agregat halus, agregat kasar, air dan kadang-kadang dengan bahan tambah yang bervariasi.

Salah satu bahan penyusun beton adalah air.Dalam fenomena sekarang ini kebutuhan air yang memenuhi syarat dalam penggunaannya sudah mulai berkurang terutama pada kota-kota besar atau pada negara-negara maju yang mana air bersih hanya diprioritaskan pada kebutuhan primer saja. Dunia teknik sipil terutama pada negara maju telah memikirkan tentang tantangan ke depan akan berkurangnya potensi air bersih (air tawar) yang dapat digunakan sebagai bahan campuran beton, terlebih pembangunan infrastruktur semakin meningkat seiring dengan penggunaan air bersih yang semakin banyak.

\subsection{Perumusan Masalah}

Maksud dari penelitian ini adalah untuk mempelajari kuat tekan beton apabila dipengaruhi dengan penambahan Natrium Chlorida $(\mathrm{NaCl})$ dan tanpa penambahan Natrium Chlorida (Beton Normal)

\subsection{Tujuan dan Manfaat Penelitian}

Adapun tujuan dari penelitian ini sebagai berikut :

1. Untuk menganalisis pengaruh penambahan Larutan $\mathrm{NaCl}$ terhadap kuat tekan beton.

2. Untuk mengevaluasi pengaruh penambahan variasi Larutan $\mathrm{NaCl}$ terhadap peningkatan kuat tekan beton.

3. Memberi kontribusi untuk perkembangan ilmu dan teknologi tentang material beton. 


\section{TINJAUAN PUSTAKA}

Struktur beton dapat definisikan sebagai bangunan beton yang terletak diatas yang menggunakan tulangan atau tidak menggunakan tulangan.Struktur beton sangat dipengaruhi oleh komposisi dan kualitas bahan-bahan pencampur beton.

\subsection{Pengertian Beton}

Beton adalah batuan buatan yang terjadi sebagai hasil pengerasan suatu campuran tertentu dari semen, air dan agregat (batu pecah, kerikil, dan pasir) hingga menjadi kenyal. beton sebagai sekumpulan interaksi mekanis dan kimiawi dari material pembentuknya [2].

Secara umum komposisi pembentuk beton adalah [3] :

1. Agregat Kasar + Agregat Halus : $(60 \%-80 \%)$ dari berat beton

2. Semen : $(7 \%-15 \%)$ dari berat beton

3. Air : $(14 \%-21 \%)$ dari berat beton

\subsection{Material Pembentuk Beton}

\section{A. Semen}

Semen merupakan bahan campuran yang secara kimiawi aktif setelah berhubungan dengan air.Agregat tidak memainkan peranan yang penting dalam reaksi kimia tersebut, tetapi berfungsi sebagai bahan pengisi mineral yang dapat mencegah perubahan-perubahan volume beton setelah pengadukan selesai dan memperbaiki keawetan beton yang dihasilkan.Sifat pengikatan semen ditentukan oleh susunan kimia yang dikandungnya.Secara umum, komposisi kimia semen Portland adalah seperti yang diperlihatkan pada tabel 2.1.

Tabel 2.1. Komposisi limit semen Portland [1]

\begin{tabular}{|l|c|}
\hline \multicolumn{1}{|c|}{ Oksida } & Komposisi (\% berat) \\
\hline $\mathrm{CaO}$ (kapur) & $60-67$ \\
$\mathrm{SiO}_{2}$ (Silika) & $17-25$ \\
$\mathrm{Al}_{2} \mathrm{O}_{3}$ (Alumina) & $3-8$ \\
$\mathrm{Fe}_{2} \mathrm{O}_{3}$ (Besi) & $0,5-6$ \\
$\mathrm{MgO}$ (Magnesia) & $0,1-5,5$ \\
$\mathrm{Alkalis}$ & $0,2-1,3$ \\
$\mathrm{SO}_{3}$ (Sulfur) & $1-3$ \\
\hline
\end{tabular}

\section{B. Agregat}

Agregat adalah butiran mineral alami yang berfungsi sebagai bahan pengisi dalam campuran beton atau mortar.Pada umumnya, semakin padat agregat-agregat tersebut tersusun, semakin kuat pula beton yang dihasilkannya, daya tahannya terhadap cuaca dan nilai ekonomis dari beton tersebut.Atas dasar inilah gradasi dari ukuran-ukuran partikel dalam agregat mempunyai peranan yang sangat penting untuk menghasilkan susunan beton yang padat.

\section{Air}

Air yang dimaksud disini adalah air yang digunakan sebagai campuran bahan bangunan, harus berupa air bersih dan tidak mengandung bahan-bahan yang dapat menurunkan kualitas beton. Persyaratan dari air yang digunakan sebagai campuran bahan bangunan adalah sebagai berikut [4] :

1. Air untuk pembuatan dan perawatan beton tidak boleh mengandung minyak, asam alkali, garam-garam, bahan-bahan organik atau bahan lain yang dapat merusak dari pada beton.

2. Apabila dipandang perlu maka contoh air dapat dibawa ke Laboratorium Penyelidikan Bahan untuk mendapatkan pengujian sebagaimana yang dipersyaratkan.

3. Jumlah air yang digunakan adukan beton dapat ditentukan dengan ukuran berat dan harus dilakukan setepat-tepatnya.

\subsection{Kuat Tekan Beton}

Pemeriksaan kuat tekan beton dilakukan untuk mengetahui secara pasti akan kekuatan tekan beton ringan pada umur 28 hari yang sebenarnya apakah sesuai dengan yang direncanakan atau tidak. Pada mesin uji tekan benda diletakkan dan diberikan beban sampai benda runtuh, yaitu pada saat beban maksimum bekerja.

Kuat tekan beton dapat dihitung dengan rumus sebagai berikut :

$$
\sigma b i=\frac{P}{A}
$$


Dengan : $\mathrm{P} \quad=$ Gaya maksimum dari mesin tekan, $\mathrm{kg}$

A = Luas penampang yang diberi tekanan, $\mathrm{cm}^{2}$

$\sigma b i=$ Kuat tekan, $\mathrm{kg} / \mathrm{cm}^{2}$

\section{METODOLOGI PENELITIAN}

\subsection{Tahap dan Prosedur Penelitian}

Dalam penelitian ini dilakukan beberapa tahapan kerja seperti:

Tahap I Persiapan bahan

Tahap II Pengujian bahan

Tahap III. 1.Pembuatan rancangan campuran beton

2.Pembuatan campuran beton

3.Pengujian Slump, Pembuatan sample, perawatan

4.Pengujian kuat tekan

Tahap IV Pengolahan data

Data - data yang dihasilkan dari pengujian di Laboratorium Dinas PU Bina Marga Provinsi Sumatera Selatan. Benda uji yang digunakan kubus dengan ukuran (15x15x15).jumlah total kubus adalah 44 buah, dengan kondisi yaitu beton yang menggunakan tambahan Natriun Clorida $(\mathrm{NaCl})$ sebesar 2\%, 3,5\% dan 5\% dengan umur 7 hari, 14 hari, 21 hari dan 28 hari.

Seluruh material untuk benda uji dilakukan pengujian kartakteristik sesuai dengan standar yang berlaku. Faktor air semen yang disesuaikan adalah 0,46. Perincian bahan untuk 6 sampel dibutuhkan semen 9,768 (kg), pasir 14,895 (kg), Batu pecah uk. $19 \mathrm{~mm} \mathrm{11,907} \mathrm{(kg),} \mathrm{Batu} \mathrm{pecah}$

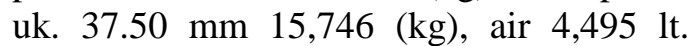
Bahan yang digunakan pada penelitian ini terdiri dari semen tipe I merek Holcim, pasir yang digunakan berasal dari Tanjung Raja, batu pecah berasal dari Merak dan air PDAM.

Benda uji kubus dibuat dengan cara memasukkan campuran beton segar ke dalam cetakan ukuran $(15 \times 15 \times 15) \mathrm{cm}$, pengisian dilakukann secara bertahap, setelah 1x24 jam cetakan dibuka kemudian dilakukan perawatan, direndam dengan air.

\section{HASIL PENGUJIAN DAN PEMBAHASAN}

\subsection{Hasil Pemeriksaan Agregat Halus}

Hasil pemeriksaan agregat halus (pasir) ex. Tanjung Raja dapat dilihat pada tabel rekapitulasi pemeriksaan agregat halus dibawah ini.

\begin{tabular}{|c|c|}
\hline \multirow{2}{*}{ Macam Pemeriksaan } & Hasil \\
\hline & Pemeriksaan \\
\hline \multicolumn{2}{|l|}{ 1. Susunan butiran: } \\
\hline Jumlah melalui & 100,00 \\
\hline$\# 4$ & 98,04 \\
\hline$\# 8$ & 89,72 \\
\hline$\# 16$ & 72,19 \\
\hline$\# 30$ & 22,15 \\
\hline$\# 50$ & 1,04 \\
\hline \# 100 & 0,22 \\
\hline \# 200 & 0,12 \\
\hline 2. Modulus kehalusan : & 3,17 \\
\hline 3. Berat isi & \\
\hline Lepas & 1,462 \\
\hline Padat & 1,551 \\
\hline 4. Berat Jenis & \\
\hline Semu & 2,59 \\
\hline Dasar kering & 2,51 \\
\hline Dasar jenuh kering permukaan & 2,54 \\
\hline Penyerapan $(\%)$ & 1,19 \\
\hline 5. Kotoran organic & No $: 3$ \\
\hline $\begin{array}{l}\text { 6. Lewat saringan No. } 200 \text { Kadar } \\
\text { lumpur }\end{array}$ & $0,60 \%$ \\
\hline
\end{tabular}

Sumber: Hasil uji Laboratorium

Dari pemeriksaan agregat halus (pasir) tersebut dapat diambil beberapa kesimpulan sebagai berikut :

1. Modulus kehalusan termasuk dalam zona I yaitu agak halus dan dibawah nilai modulus yang disyarat kan 2,00 sampai 3,00 . 
Hasil Analisa saringan dan Spec Gradasi Pasir

\begin{tabular}{|c|c|c|c|c|c|}
\hline \multirow{2}{*}{$\begin{array}{c}\text { Lubang } \\
\text { Ayakan } \\
(\mathrm{mm})\end{array}$} & \multicolumn{4}{|c|}{ Persen Berat Butir yang Lewat Ayakan } \\
\cline { 3 - 6 } & Hasil & \multicolumn{4}{|c|}{ Spec } \\
\cline { 3 - 6 } & Analisa & Zone I & Zone II & Zone III & Zone IV \\
\hline 10 & 100 & 100 & 100 & 100 & 100 \\
\hline 4,8 & 98,04 & $90-100$ & $90-100$ & $90-100$ & $95-100$ \\
\hline 2,4 & 89,72 & $60-95$ & $75-100$ & $85-100$ & $95-100$ \\
\hline 1,2 & 72,19 & $30-70$ & $55-90$ & $75-100$ & $90-100$ \\
\hline 0,6 & 22,15 & $15-34$ & $35-59$ & $60-79$ & $80-100$ \\
\hline 0,3 & 1,04 & $5-20$ & $8-30$ & $12-40$ & $15-50$ \\
\hline 0,15 & 0,22 & $0-10$ & $0-10$ & $0-10$ & $0-15$ \\
\hline
\end{tabular}

Sumber: Hasil uji Laboratorium

Grafik Gradasi Pasir daerah zona 1 (Kasar)

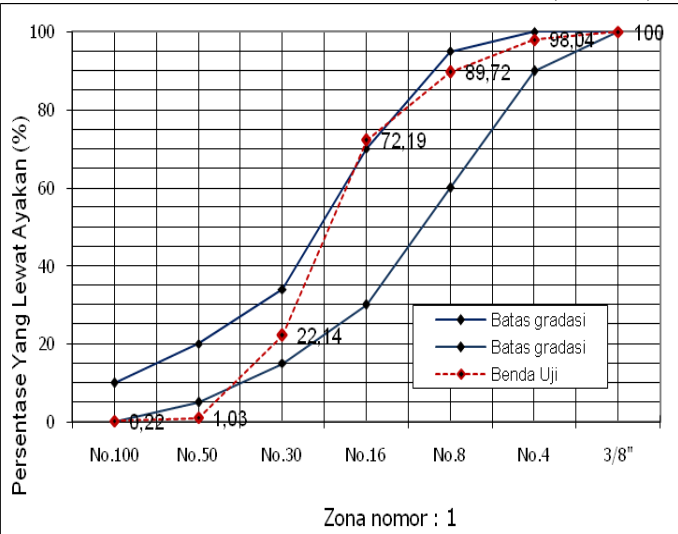

Sumber: Hasil uji Laboratorium

2. Kotoran organik melebihi standar warna yang disyaratkan yaitu no.3 untuk kadar organik yang standar warnanya no. 4 dan 5 perlu dilakukan pencucian agregat halus sebelum digunakan.

3. Kadar lumpur yaitu $0,60 \%$, dikategorikan memenuhi syarat dari kadar lumpur maksimal yang diijinkan yaitu $5 \%$.

\subsection{Hasil Pemeriksaan Agregat Kasar}

Hasil pemeriksaan agregat kasar (batu pecah) ex. Merak dapat dilihat pada tabel rekapitulasi pemeriksaan agregat halus dibawah ini.

\section{Rekapitulasi Pemeriksaan Agregat Kasar}

\begin{tabular}{|c|c|c|}
\hline \multirow{3}{*}{ Macam Pemeriksaan } & \multicolumn{2}{|c|}{ HasilPemeriksaan } \\
\hline & Agregat & Agregat \\
\hline & $19.00 \mathrm{~mm}(3 / 4 ")$ & $37,50 \mathrm{~mm}\left(1^{1} / 2 "\right)$ \\
\hline \multicolumn{3}{|l|}{ 1. Susunan butiran: } \\
\hline \multirow[t]{6}{*}{ Jumlah melalui } & & 100,00 \\
\hline & 100,00 & 53,63 \\
\hline & 87,98 & 16,50 \\
\hline & 49,32 & 2,43 \\
\hline & 19,59 & 0,00 \\
\hline & 0,00 & \\
\hline 2. Modulus kehalusan : & 6,92 & 7,83 \\
\hline \multicolumn{3}{|l|}{ 3. Berat isi } \\
\hline Lepas & 1,337 & 1,330 \\
\hline Padat & 1,415 & 1,419 \\
\hline \multicolumn{3}{|l|}{ 4. Berat Jenis } \\
\hline Semu & 2,67 & 2,67 \\
\hline Dasar kering & 2,52 & 2,53 \\
\hline Dasar jenuh kering permukaan & 2,57 & 2,58 \\
\hline Penyerapan (\%) & 2,26 & 2,10 \\
\hline 5. Keausan (\%) & - & $23,24 \%$ \\
\hline
\end{tabular}

Sumber: Hasil uji Laboratorium

Dari pemeriksaan agregat kasar

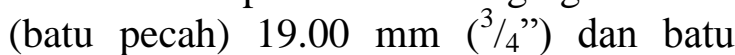
pecah 37,50 $\mathrm{mm}\left(1_{1 / 2 ")}\right)$ tersebut dapat diambil beberapa kesimpulan berikut :

1. Modulus kehalusan memenuhi syarat yaitu antara $6-8$.

2. Keausan memenuhi standar normal yang diijinkan.

\subsection{Kuat Tekan Beton}

A. Tabel Rekapitulasi Kuat Tekan Beton

\begin{tabular}{|c|c|c|c|c|}
\hline No. & $\begin{array}{c}\text { Persentase } \\
\text { Penambahan } \\
\mathrm{NaCl}\end{array}$ & $\begin{array}{c}\text { Umur } \\
(\text { hari) }\end{array}$ & $\begin{array}{c}\text { Deviasi } \\
\text { Standar (S) }\end{array}$ & $\begin{array}{c}\text { Kuat Tekan } \\
\text { Beton } \\
\text { Karateristik } \\
(\sigma \mathrm{bk}) \mathrm{kg} / \mathrm{cm}^{2}\end{array}$ \\
\hline 1. & $0 \%$ (Normal) & 7 & 2,58 & 215,58 \\
\hline & $2 \%$ & 7 & 5,22 & 195,69 \\
\hline & $3,5 \%$ & 7 & 5,40 & 178,33 \\
\hline & $5 \%$ & 7 & 7,08 & 164,71 \\
\hline
\end{tabular}




\begin{tabular}{|c|c|c|c|c|}
\hline 2. & $0 \%$ (Normal) & 14 & 4,54 & 247,84 \\
\hline & $2 \%$ & 14 & 4,37 & 238,76 \\
\hline & $3,5 \%$ & 14 & 4,53 & 225,81 \\
\hline & $5 \%$ & 14 & 5,66 & 214,59 \\
\hline 3. & $0 \%$ (Normal) & 21 & 3,18 & 258,67 \\
\hline & $2 \%$ & 21 & 2,72 & 284,34 \\
\hline & $3,5 \%$ & 21 & 6,28 & 230,03 \\
\hline & $5 \%$ & 21 & 4,21 & 223,32 \\
\hline 4. & $0 \%$ (Normal) & 28 & 4,46 & 312,42 \\
\hline & $2 \%$ & 28 & 4,65 & 284,34 \\
\hline & $3,5 \%$ & 28 & 3,59 & 276,25 \\
\hline & $5 \%$ & 28 & 3,96 & 266,45 \\
\hline
\end{tabular}

Sumber : Hasil uji Laboratorium

Berdasarkan tabel diatas dapat dilihat deviasi standar (S) pada saat melakukan Penelitian antara 2,58 sampai 7,08 dapat disimpulkan bahwa dalam pengadukan pembuatan kubus beton adukan betonnya homogen, apabila nilai deviasi standar itu besar itu berarti adukan beton segar tidak homogen itu dapat mempengaruhi kuat tekan beton.

Makin kecil nilai standar deviasi yang didapat maka makin besar kuat tekan betonnya, Makin besar nilai standar deviasi yang didapat maka makin kecil kuat tekan betonnya.

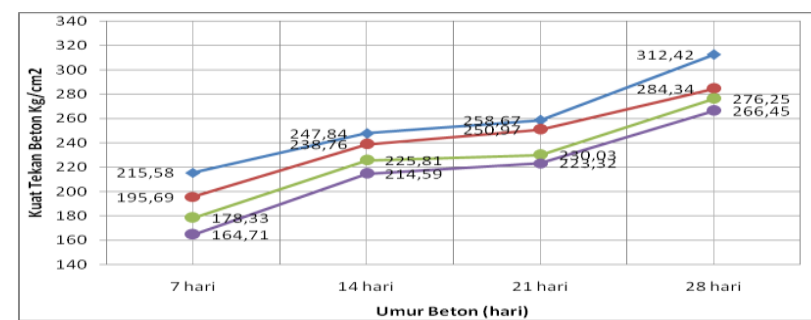

Keterangan gambar

\begin{tabular}{|l|c|c|c|c|c|c|}
\hline \multirow{2}{*}{ Kondisi Beton } & Ket. & \multicolumn{4}{|c|}{ Umur Beton (hari) } & \multirow{2}{*}{$\sigma \mathrm{bk}$} \\
\cline { 3 - 6 } & Warna & 7 hari & 14 hari & 21 hari & 28 hari & \\
\hline Beton Normal & & 215,58 & 247,84 & 258,67 & 312,42 & $\mathrm{Kg} / \mathrm{cm}^{2}$ \\
\hline $\begin{array}{l}\text { Beton Normal dengan } \\
\text { Penambahan 2\% NaCl }\end{array}$ & & 195,69 & 238,76 & 250,97 & 284,34 & $\mathrm{Kg} / \mathrm{cm}^{2}$ \\
\hline $\begin{array}{l}\text { Beton Normal dengan } \\
\text { Penambahan 3,5\% } \\
\text { NaCl }\end{array}$ & 178,33 & 225,81 & 230,03 & 276,25 & $\mathrm{Kg} / \mathrm{cm}^{2}$ \\
\hline $\begin{array}{l}\text { Beton Normal dengan } \\
\text { Penambahan 5\% NaCl }\end{array}$ & & 164,71 & 214,59 & 223,32 & 266,45 & $\mathrm{Kg} / \mathrm{cm}^{2}$ \\
\hline
\end{tabular}

Sumber : Hasil uji Laboratorium
Dari grafik diatas dapat kita lihat bahwa campuran beton dengan penambahan $\mathrm{NaCl}$ tidak dapat meningkatkan kuat tekan beton karakteristik dimana saat penambahan 2\% pada umur 28 hari dengan ketercapaian kuat tekan beton $284,34 \mathrm{~kg} / \mathrm{cm}^{2}$, penambahan $3,5 \%$ pada umur 28 hari dengan ketercapaian kuat tekan beton $276,25 \mathrm{~kg} / \mathrm{cm}^{2}$ dan penambahan $5 \%$ pada umur 28 hari dengan ketercapaian kuat tekan beton $266,45 \mathrm{~kg} / \mathrm{cm}^{2}$ jika dibandingkan dengan kuat tekan beton normal 28 hari yaitu $312,42 \mathrm{~kg} / \mathrm{cm}^{2}$ yang mencapai kuat tekan beton yang disyaratkan yaitu $250 \mathrm{~kg} / \mathrm{cm}^{2}$.

Penambahan $\mathrm{NaCl}$ dalam campuran beton normal dapat menurunkan kuat tekan beton karakteristik, persentase penurunan dapat dilihat pada tabel dibawah ini.

Tabel Persentase Kenaikan Kuat Tekan Beton

\begin{tabular}{|c|c|c|}
\hline $\begin{array}{c}\text { Persentase } \\
\text { Penambahan } \\
\mathrm{NaCl}\end{array}$ & $\begin{array}{c}\sigma \mathrm{bk} \\
\text { Umur } \\
\text { beton 28 } \\
\text { Hari } \\
\mathrm{Kg} / \mathrm{cm}^{2}\end{array}$ & Persentase \\
\hline $0 \%$ (normal) & 312,42 & - \\
\hline $2 \%$ & 284,34 & $8,99 \%$ \\
\hline $3,5 \%$ & 276,25 & $11,58 \%$ \\
\hline $5 \%$ & 266,45 & $14,71 \%$ \\
\hline
\end{tabular}

\section{Sumber: Hasil uji Laboratorium}

Dari tabel diatas dapat kita dapat lihat bahwa campuran beton dengan penambahan $\mathrm{NaCl} 2 \%$ pada umur 28 hari mengalami penurunan $8,99 \%$, penambahan $\mathrm{NaCl} 3,5 \%$ pada umur 28 hari mengalami penurunan $11,58 \%$ dan penambahan $\mathrm{NaCl} 5 \%$ pada umur 28 hari mengalami penurunan $14,71 \%$ dari kuat tekan beton normal.

\section{KESIMPULAN DAN SARAN 5.1 Kesimpulan}

Dari pembahasan yang dilakukan, bahwa dengan penambahan $\mathrm{NaCl}$ tidak dapat meningkatkan kuat tekan beton, penambahan $\mathrm{NaCl} 2 \%$ pada umur 28 hari dengan ketercapaian kuat tekan tekan beton 284,34 $\mathrm{kg} / \mathrm{cm}^{2}$, penambahan $3,5 \%$ pada umur 28 hari 
dengan ketercapaian kuat tekan beton $276,25 \mathrm{~kg} / \mathrm{cm}^{2}$ dan penambahan $5 \%$ pada umur 28 hari dengan ketercapain kuat tekan beton $266,45 \mathrm{~kg} / \mathrm{cm}^{2}$. Jika dibandingkan dengan dengan kuat tekan beton normal 28 hari yaitu $312,42 \mathrm{~kg} / \mathrm{cm}^{2}$ yang mencapai kuat tekan beton yang diisyaratkan yaitu $250 \mathrm{~kg} / \mathrm{cm}^{2}$.

\subsection{Saran}

Setelah melakukan penelitian dengan penambahan $\mathrm{NaCl}$ penulis dapat memberi saran sebagai berikut :

1. Pemilihan bahan-bahan pembuatan beton yang akan digunakan hendaklah memiliki mutu baik dan memenuhi syarat-syarat yang telah ditentukan, serta pelaksanaan pengerjaan beton sesuai dengan mekanisme yang telah ditentukan.

2. Untuk mengetahui batasan maksimum penambahan $\mathrm{NaCl}$ pada campuran beton dengan mutu K.250 perlu dilakukan penelitian lebih lanjut.

\section{DAFTAR PUSTAKA}

[1] A.M. Neville, Concrete Technology, 1987

[2] Edward G. Nawy. Prentice Hall, 1989 Technology \& Engineering.

[3] Mulyono, Tri. 2003. "Teknologi Beton". Penerbit Andi. Jakarta

[4] Departemen Pekerjaan Umum, 1971, Peraturan eton Indonesia (PBI 1971), Departemen Pekerjaan Umum, Jakarta.

[5] SNI 03-2834-2000 "Tata Cara Pembuatan Beton Normal"

[6] SNI 03-1972-1990 "Metode Pengujian Slump Beton"

[7] SNI 03-1974-1990 "Metode Pengujian Kuat Tekan Beton" 